\title{
Analisis Rasio Modal, Efisiensi Operasional, Bunga Bersih, Likuiditas, Dan Kredit Bermasalah, Terhadap Rasio Laba
}

\author{
Studi Pada Bank Umum Konvensional Di Indonesia \\ Rahmat \\ Endang Ruchiyat \\ Sekolah Tinggi Ilmu Ekonomi Ekuitas \\ rahmat@ekuitas.ac.id \\ endang.ruchiyat@ekuitas.ac.id
}

\begin{abstract}
ABSTRAK
Penelitian ini bertujuan untuk menganalisis Rasio-rasio keuangan yang meliputi Rasio Permodalan, Rasio Efisiensi Operasional, Rasio Bunga bersih, Rasio likuiditas, Rasio Kredit bermasalah terhadap Rasio Laba pada Bank Umum Konvensional di Indonesia. Bank yang diteliti didasarkan atas pengelompokan bank ditinjau dari kategori kepemilikan yang meliputi Bank Persero, Bank Umum Swasta Nasional Devisa, Bank Umum Swasta Nasional Non Devisa, Bank Pembangunan Daerah, Bank Campuran, dan Bank Asing. Teknik analisis yang digunakan yaitu analisis regresi berganda. Karena data yang digunakan adalah data sekunder, maka untuk menentukan ketepatan model perlu dilakukan pengujian atas beberapa asumsi klasik yang mendasari model regresi. Pengujian asumsi klasik yang digunakan dalam penelitian ini meliputi uji, normalitas, multikolinearitas, heteroskedastisitas dan autokorelasi. Selanjutnya untuk Menguji pengaruh Rasio-rasio keuangan sebagaimana disebutkan, digunakan uji statistik dengan Regresi Linear Berganda. Berdasarkan Penelitian dihasilkan bahwa Rasio Modal, Efisiensi Operasional, Hasil Bunga, Likuiditas, dan Kredit bermasalah berpengaruh terhadap laba bank.
\end{abstract}

Kata Kunci: Rasio-rasio Keuangan, Laba Bank

\begin{abstract}
This study aims to analyze financial ratios which include Capital Ratios, Operational Efficiency Ratios, Net Interest Ratios, Liquidity Ratios, Non-Performing Loans Ratios to Profit Ratios at Conventional Commercial Banks in Indonesia. The banks studied were based on bank grouping in terms of ownership category which included State-Owned Banks, National Private Foreign Exchange Banks, National Private Non-Foreign Exchange Banks, Regional Development Banks, Joint Venture Banks, and Foreign Banks. The analysis technique used is multiple regression analysis. Because the data used is secondary data, to determine the accuracy of the model, it is necessary to test several classical assumptions that underlie the regression model. Classical assumption tests used in this study include tests, normality, multicollinearity, heteroscedasticity and autocorrelation. Furthermore, to test the effect of financial ratios as mentioned, statistical tests withused Multiple Linear Regression were. Based on the research, it is found that the Capital Ratio, Operational Efficiency, Interest Yield, Liquidity, and Non-Performing Loans affect bank profits.
\end{abstract}

Keywords: Financial Ratios, Bank Profit

\section{PENDAHULUAN}

Rasio Keuangan pada perusahaan termasuk juga pada perbankan merupakan suatu indikator untuk menganalisis Kinerja, baik perkembangan usaha maupun tingkat kesehatan bank, sehingga hasil analisisnya dapat dijadikan sebagai alat pengambilan keputusan untuk dijadikan strategi bisnis bank dimasa yang akan datang dalam upaya lebih meningkatkan kinerja yang lebih baik. Tujuan laporan keuangan adalah memberikan informasi keuangan yang mencakup perubahan dari unsur-unsur laporan keuangan yang ditujukan kepada pihak-pihak lain yang berkepentingan dalam menilai kinerja keuangan terhadap perusahaan di samping pihak manajemen perusahaan (Irham Fahmi 2011). 
Menurut Samryn (2011), Analisis Rasio Keuangan adalah suatu cara yang membuat perbandingan data keuangan perusahaan menjadi lebih arti. Rasio keuangan menjadi dasar utk menjawab beberapa pertanyaan penting mengenai kesehatan keuangan dari perusahaan.

Kinerja keuangan pada perbankan salah satunya diukur dengan Laba bank.

Indikator indikator yang lazim dan sering digunakan pada lembaga keuangan perbankan yang akan dibahas dalam penelitian ini adalah Rasio Permodalan dengan rumus Capital Adequacy Ratio (CAR), Efisiensi Operasional dengan menggunakan Rumus BOPO atau Ratio Efficiency Operational (REO), Rasio Margin Bunga dengan menggunakan rumus Net Interest Margin (NIM), Rasio Likuiditas dengan menggunakan rumus Loan To Deposit Ratio (LDR), dan rasio kualitas kredit dengan rumus yang digunakan adalah Non Performing Loan (NPL). Selanjutnya akan dianalisis sejauh mana pengaruhnya terhadap Kinerja Bank dimana yang akan dijadikan ukuran adalah Laba bank dengan menggunakan rumus Return On Asset (ROA).

CAR (Capital Adequacy Ratio) merupakan rasio kecukupan modal yang menunjukkan kemampuan perbankan dalam menyediakan dana yang digunakan untuk mengatasi kemungkinan risiko kerugian. Rasio ini penting karena dengan menjaga CAR pada batas aman, berarti juga melindungi nasabah dan menjaga stabilitas sistem keuangan secara keseluruhan. Semakin besar nilai CAR mencerminkan kemampuan perbankan yang semakin baik dalam menghadapi kemungkinan risiko kerugian. CAR dapat diperoleh dengan membagi total modal dengan aset tertimbang menurut risiko (ATMR),

BOPO (Biaya Operasional terhadap Pendapatan Operasional) atau ROE merupakan rasio yang menggambarkan efisiensi perbankan dalam melakukan kegiatannya. Biaya operasional adalah biaya operasional Bank sedangkan pendapatan operasional adalah Pendapatan Operasional bank. Semakin kecil nilai BOPO artinya semakin efisien perbankan dalam beroperasi.. NIM adalah ukuran selisih antara bunga yang diterima oleh bank dan bunga yang dibayarkan bank kepada nasabah penyimpan Dana.

LDR (Loan to Deposits Ratio) adalah rasio yang mengukur kemampuan bank dalam memenuhi kewajiban jangka pendek (bisa disebut likuiditas) dengan membagi total kredit terhadap total Dana Pihak Ketiga (DPK). Likuiditas perbankan perlu dikelola guna memenuhi kebutuhan saat nasabah mengambil dananya dan menyalurkan pinjaman (kredit) kepada peminjam (debitur). Jika nilai LDR terlalu tinggi, artinya perbankan tidak memiliki likuiditas yang cukup memadai untuk menutup kewajibannya terhadap nasabah (DPK). Sebaliknya, jika nilai LDR terlalu rendah berarti perbankan memiliki likuiditas yang cukup memadai tetapi mungkin pendapatannya lebih rendah, karena seperti yang diketahui dunia perbankan memperoleh pendapatan melalui kredit yang disalurkan. LDR dapat dihitung dengan cara:

NPL (Non Performing Loan) adalah salah satu indikator penilaian terhadap dana yang disalurkan berupa kredit atau yang setara, semakin kecil rasio ini menunjukan kualitas yang makin baik.

ROA (Return On Assets) merupakan rasio yang mengukur kemampuan perbankan dalam menghasilkan laba dengan cara membandingkan laba bersih dengan total aset yang dimiliki. Fungsinya adalah untuk melihat seberapa efektif perbankan dalam menggunakan asetnya dalam menghasilkan pendapatan. Semakin besar nilai ROA artinya semakin baik kemampuan perbankan dalam menghasilkan laba.

Penelitian Rasio-rasio tersebut dilakukan terhadap kelompok bank yang ada di Indonesia meliputi Bank Persero, Bank Umum Swasta Nasional (BUSN) Devisa dan Non Devisa, Bank Pembangunan Daerah, Bank Campuran, sehingga dapat diketahui kelompok Bank mana yang Rasio keuangannya yang paling berpengaruh terhadap kinerjanya berdasarkan laba yang dihasilkan. Dalam penelitian ini digunakan alat berupa aplikasi SPSS versi IBM 24.

\section{KAJIAN PUSTAKA}

\section{Rasio Keuangan}

Rasio Keuangan menurut Bambang Riyanto (2001:329) adalah ukuran yang digunakan dalam interpretasi dan analisis laporan finansial suatu perusahaan. Pengertian rasio itu sebenarnya hanyalah alat yang dinyatakan dalam arithmatical terms yang dapat digunakan untuk menjelaskan hubungan antara dua macam data finansial.Sedangkan menurut S. Munawir (2007:65) adalah Suatu metode analisis untuk mengetahui hubungan dari pos-pos tertentu dalam neraca atau laporan laba rugi secara individu atau kombinasi dari kedua laporan tersebut. Analisis rasio keuangan memberikan kerangka hubungan antar pos-pos neraca dan perhitungan laba rugi, memungkinkan seseorang menelusuri sejarah suatu perusahaan dan menilai posisi keuangannya saat ini, serta memungkinkan bagi manajer keuangan memperkirakan reaksi kreditur atau investor terhadap keadaan keuangan perusahaan dan dengan demikian dapat mencari cara-cara yang tepat untuk mendapatkan dana Weston (1995:225). Menurut Agus Sartono (2001:113) Dasar untuk menilai dan mengarahkan prestasi operasi perusahaan. Disamping itu, analisa rasio keuangan juga dapat dipergunakan sebagai kerangka kerja perencanaan dan pengendalian keuangan." Rasio Profitabilitas menjadi perhatian dalam analisis laporan keuangan karena dianggap sudah 
menjelaskan kondisi suatu perusahaan. Rasio profitabilitas bermanfaat untuk menunjukkan keberhasilan perusahaan di dalam menghasilkan keuntungan. Rasio profitabilitas menurut Sutrisno (2009:16) rasio profitabilitas adalah kemampuan perusahaan dalam menghasilkan keuntungan dengan semua modal yang bekerja didalamnya. 19 Sedangkan menurut Fahmi (2012:135) rasio profitabilitas adalah: "Mengukur efektivitas manajemen secara keseluruhan yang ditunjukkan oleh besar kecilnya tingkat keuntungan yang diperoleh dalam hubungannya dengan penjualan maupun investasi. Semakin baik rasio profitabilitas maka akan semakin baik menggambarkan kemampuan tingginya perolehan keuntungan perusahaan." Dari teori diatas dapat diambil kesimpulan bahwa rasio profitabilitas adalah rasio yang mengukur kemampuan dan efektivitas untuk menghasilkan laba.

CAR adalah kecukupan modal yang menunjukkan bank dalam mempertahankan modal yang mencukupi dan kemampuan manajemen bank dalam mengidentifikasi, mengukur, mengawasi, dan mengontrol resiko-resiko yang timbul yang dapat berpengaruh terhadap besarnya modal bank (Kuncoro 2011:519). Menurut Peraturan Bank Indonesia Nomor 9/13/PBI/2007 CAR adalah penyediaan modal minimum bagi bank didasarkan pada risiko aktiva dalam arti luas, baik aktiva yang tercantum dalam neraca maupun aktiva yang bersifat administratif sebagaimana tercermin pada kewajiban yang masih bersifat kontinjen dan/atau komitmen yang disediakan oleh bank bagi pihak ketiga maupun risiko pasar."

Biaya Operasional terhadap Pendapatan Operasional (BOPO) Analisis rasio efisiensi operasional menurut Dendawijaya (2009:111) menggunakan perhitungan: 1. Biaya Operasional adalah biaya yang berhubungan dengan kegiatan usaha bank, yaitu biaya bunga, biaya valuta asing lainnya, biaya tenaga kerja, penyusutan dan biaya lainnya. 2. Pendapatan Operasional adalah semua pendapatan yang merupakan hasil langsung dari kegiatan usaha bank yang benar-benar diterima, seperti hasil bunga, provisi dan komisi, pendapatan valuta asing lainnya dan pendapatan lainnya. Masalah efisiensi berkaitan dengan masalah pengendalian biaya. Efisiensi operasional berarti biaya yang dikeluarkan untuk menghasilkan keuntungan lebih 21 kecil daripada keuntungan yang diperoleh dari penggunaan aktiva tersebut. Bank yang tidak mampu memperbaiki tingkat efisiensi usahanya maka akan kehilangan daya saing baik dalam hal mengerahkan dana masyarakat maupun dalam hal penyaluran dana tersebut dalam bentuk modal usaha. Efisiensi dapat diukur dengan rasio Biaya Operasional terhadap Pendapatan Operasional (BOPO). Menurut Rivai dkk (2007:722) pengertian BOPO adalah perbandingan antara Biaya Operasional dengan Pendapatan Operasional dalam mengukur tingkat efisiensi dan kemampuan bank dalam melakukan kegiatan operasinya.

Net Interest Margin (NIM) merupakan salah satu indikator yang diperhitungkan dalam penilaian aspek profitabilitas. NIM merupakan rasio yang dipergunakan untuk mengukur kemampuan manajemen bank dalam mengelola aktiva produktifnya dalam rangka menghasilkan pendapatan bunga bersih. Menurut Taswan (2010:167) Net Interest Margin (NIM) adalah: Perbandingan antara pendapatan bunga bersih terhadap rata-rata aktiva produktif. Rasio ini mengindikasi kemampuan bank menghasilkan pendapatan bunga bersih dengan penempatan aktiva produktif. Semakin besar rasio ini semakin baik kinerja bank dalam menghasilkan pendapatan bunga. Namun harus dipastikan bahwa ini bukan karena biaya intermediasi yang tinggi, asumsinya pendapatan bunga harus ditanamkan kembali untuk memperkuat modal bank. Menurut Riyadi (2009:21) Net Interest Margin (NIM) adalah: Perbandingan antara pendapatan bunga bank dikurangi biaya bunga bank dibagi rata-rata aktiva produktif. Pendapatan bunga bersih diperoleh dari pendapatan bunga dikurangi beban bunga. Semakin besar rasio ini maka semakin meningkat pula pendapatan bunga atas aktiva produktif yang dikelola bank, sehingga kemungkinan bank dalam kondisi bermasalah semakin kecil.

Likuiditas menurut Darmawi (2011:59) adalah suatu istilah yang dipakai untuk menunjukkan persediaan uang tunai dan asset lain yang dengan mudah dijadikan uang tunai. Alat ukur likuiditas yang sering digunakan adalah rasio LDR (Loan to Deposit Ratio). Agar definisi LDR menjadi lebih jelas, peneliti mengutip beberapa definisi yang dikemukakan oleh para ahli sebagai berikut: Menurut Kasmir (2014:225) LDR (Loan to Deposit Ratio) adalah rasio yang digunakan untuk mengukur komposisi jumlah kredit yang diberikan dibandingkan dengan jumlah dana masyarakat dan modal sendiri yang digunakan." Menurut Darmawi (2011:61) LDR (Loan to Deposit Ratio) adalah salah satu ukuran likuid dari konsep persediaan yang berbentuk rasio pinjaman terhadap deposit." Dari pengertian LDR menurut para ahli diatas, maka dapat disimpulkan bahwa LDR adalah rasio yang mengukur sejauh mana kemampuan bank dalam membayar kembali penarikan dana yang dilakukan deposan dengan mengandalkan kredit yang diberikan sebagai sumber likuiditasnya. Semakin tinggi rasio ini maka semakin rendahnya likuiditas bank yang bersangkutan. Namun sebaliknya, jika semakin rendah rasio LDR maka semakin tinggi likuiditas bank yang bersangkutan. Rasio ini juga merupakan indikator kerawanan dan kemampuan dari suatu bank. Menurut Kasmir (2014:225), batas aman dari LDR suatu bank adalah sekitar $80 \%$. Namun batas maksimal LDR adalah $110 \%$. Rasio LDR dihitung dengan membandingkan kredit dengan dana pihak ketiga dimana kredit yang digunakan merupakan total kredit yang diberikan kepada pihak ketiga, dan tidak termasuk kredit yang diberikan kepada pihak lain. Sedangkan dana pihak ketiga merupakan giro, tabungan, dan 
deposito yang tidak termasuk antar bank.

Non Performing Loan (NPL), Dalam melakukan pemberian kredit kepada nasabah, bank akan dihadapkan pada risiko kredit yang tidak mampu dibayar oleh debitur sehingga menimbulkan kredit bermasalah. Menurut Ismail (2009:224), kredit bermasalah yaitu suatu keadaan dimana nasabah sudah tidak sanggup membayar sebagian atau seluruh kewajibannya kepada bank seperti yang telah diperjanjikan. Setiap bank harus mampu mengelola kreditnya dengan baik dalam memberikan kredit kepada masyarakat 15 maupun dalam pengembalian kreditnya sesuai dengan syarat dan ketentuan yang berlaku sehingga tidak menimbulkan kredit bermasalah. Menurut Ismail (2009:226). NPL (Non Performing Loan) adalah kredit yang menunggak melebihi 90 hari. Dimana NPL terbagi menjadi Kredit Kurang Lancar, Diragukan, dan Macet.” Menurut Taswan (2006:389), rasio yang digunakan untuk menilai kinerja keuangan dalam mengelola kredit bermasalah adalah rasio NPL (Non Performing Loan). Kredit bermasalah digolongkan ke dalam Kolektibilitas, Lancar, Kurang Lancar, Diragukan, dan Macet. Semakin kecil NPL maka semakin kecil pula risiko kredit yang ditanggung oleh pihak bank. Bank dalam melakukan kredit harus melakukan analisis terhadap kemampuan debitur untuk membayar kembali kewajibannya. Setelah kredit diberikan, bank wajib melakukan pemantauan terhadap penggunaan kredit serta kemampuan dan kepatuhan debitur dalam memenuhi kewajibannya. Bank melakukan peninjauan dan pengikatan terhadap agunan untuk memperkecil risiko kredit. Praktisi perbankan menyepakati bahwa batas aman dari NPL suatu bank tidak boleh melebihi $5 \%$.

Return on Assets (ROA) Dalam penentuan tingkat kesehatan suatu bank, Bank Indonesia lebih mementingkan penilaian besarnya Return on Assets (ROA), karena Bank Indonesia sebagai pembina dan pengawas perbankan lebih mengutamakan nilai profitabilitas suatu bank yang diukur dengan asset yang dananya sebagian besar berasal dari dana simpanan masyarakat (Dendawijaya, 2009:119). Menurut Hanafi dan Halim (2009:157) Return on Assets (ROA) mengukur kemampuan perusahaan menghasilkan laba dengan biaya-biaya untuk mendanai aset tersebut. 23 Sedangkan menurut Mardiyanto (2009:196) Return on Assets (ROA) adalah rasio yang digunakan untuk mengukur kemampuan perusahaan dalam menghasilkan laba yang berasal dari aktivitas investasi. Rumus perhitungan yang digunakan mengacu pada Surat Edaran Bank Indonesia No.6/ 23/DPNP tanggal 31 Mei 2004 dan Surat Edaran Otoritas Jasa Keuangan Nomor 14 /SEOJK.03/2017 tentang penilaian tingkat kesehatan bank umum sebagai berikut:
Tabel 1. Penilaian Tingkat Kesehatan Bank Umum

\begin{tabular}{|c|c|c|c|c|}
\hline No & $\begin{array}{l}\text { Jenis } \\
\text { Rasio }\end{array}$ & & Rumus Perhitung & \\
\hline \multirow{2}{*}{1} & \multirow{2}{*}{ Permodalan } & \multirow{2}{*}{ CAR } & Total Modal & \multirow{2}{*}{ X $100 \%$} \\
\hline & & & ATMR & \\
\hline \multirow[b]{2}{*}{2} & \multirow[b]{2}{*}{ Efisiensi } & \multirow[b]{2}{*}{ BOPO } & Biaya Operasional & \multirow[b]{2}{*}{ X $100 \%$} \\
\hline & & & Pendapatan Operasional & \\
\hline \multirow[t]{2}{*}{3} & \multirow{2}{*}{\multicolumn{2}{|c|}{ Bunga bersihNIM }} & Pendapatan Bunga Bersih & \multirow{2}{*}{ X $100 \%$} \\
\hline & & & Rata-rata aktiva Produktif & \\
\hline \multirow{2}{*}{4} & \multirow[b]{2}{*}{ Likuiditas } & \multirow{2}{*}{ LDR } & Kredit & \multirow[b]{2}{*}{ X $100 \%$} \\
\hline & & & Dana Pihak Ketiga & \\
\hline \multirow[b]{2}{*}{5} & \multirow{2}{*}{\multicolumn{2}{|c|}{ Kualitas Kre(NPL }} & Kredit Bermasalah & \multirow[b]{2}{*}{ X $100 \%$} \\
\hline & & & Total Kredit & \\
\hline \multirow[b]{2}{*}{6} & \multirow{2}{*}{ Laba } & \multirow{2}{*}{ ROA } & Laba bersih sebelum pajak & \multirow{2}{*}{ X $100 \%$} \\
\hline & & & Eata-rata Total Asset & \\
\hline
\end{tabular}

\section{Penelitian Terdahulu}

1. Ririn Poerwanti dan Titis Puspitaningrum Dewi Kartika (2018) Dalam Penelitiannya menyatakan bahwa Rasio keuangan yang dinilai dari CAR, NPL dan LDR sebelum melibatkan variabel pertumbuhan kredit yang signifikan mempengaruhi peningkatan laba di Bank Pembangunan Daerah di Jawa, Bali dan NTT yang dibuktikan dengan hasil uji simultan dengan P-value dari F atau signifikansi $0,019<\mathrm{a}$ '(5\%), Rasio CAR, NPL dan LDR secara signifikan mempengaruhi pertumbuhan kredit di Bank Pembangunan Daerah di Jawa, Bali dan NTT melalui pengujian simultan dengan nilai $\mathrm{P}$ atau tingkat signifikansi $0,004<\mathrm{a}{ }^{\prime}(5 \%)$.

2. Monica (2019) Penelitian ini telah dilakukan dengan menggunakan metode purposive sampling dengan dua kriteria sehingga 20 perusahaan telah dipilih sebagai sampel. Teknik analisis telah dilakukan dengan menggunakan regresi linier berganda. Hasil penelitian menunjukkan bahwa CAR, NIM, dan LDR tidak berpengaruh terhadap ROE, sedangkan NPL dan BOPO berpengaruh negatif terhadap ROE. Dimana terbukti bahwa secara bersama-sama CAR, NPL, NIM, BOPO, dan LDR memiliki pengaruh terhadap ROE.

3. Catur Wahyu Endra Yogianta (2013), Penelitian ini dilakukan untuk menguji pengaruh variabel CAR, NIM, LDR, NPL, dan BOPO, terhadap ROA. Permasalahan dalam penelitian ini adalah adanya research gap dari penelitian terdahulu dan fenomena business gap dari data kelompok bank umum di Indonesia, tahun 2002-2010 pada Statistik Perbankan Indonesia sehingga perlu dilakukan penelitian lanjutan yang meneliti permasalahan faktor-faktor yang mempengaruhi Return On Asset (ROA) dengan didasari oleh teori yang mendasar. Faktor-faktor tersebut terdiri dari variabel CAR, 
Net Interest Margin (NIM), Loan to Deposit Ratio (LDR), Non Performing Loan (NPL), dan Biaya Operasional terhadap Pendapatan Operasional (BOPO). Teknik sampling yang digunakan adalah purposive sampling dengan kriteria bank umum di Indonesia yang menyajikan laporan keuangan periode 2002 sampai dengan 2010 dan bank umum yang memperoleh laba periode 2002-2010. Data diperoleh berdasarkan publikasi Direktori Perbankan Indonesia periode tahun 2002 sampai dengan tahun 2010. Diperoleh jumlah sampel sebanyak 16 perusahaan dari 26 bank umum di Indonesia periode 2002-2010. Teknik analisis yang digunakan adalah regresi berganda dengan persamaan kuadrat terkecil dan uji hipotesis menggunakan t-statistik untuk menguji koefisien regresi parsial serta statistik untuk menguji keberartian pengaruh secara bersama-sama dengan level of significance 5\%. Selain itu juga dilakukan uji asumsi klasik yang meliputi uji normalitas, uji multikolinieritas, uji heteroskedastisitas dan uji autokorelasi. Selama periode pengamatan menunjukkan bahwa data penelitian berdistribusi normal. Berdasarkan uji multikolinieritas, uji heteroskedastisitas dan uji autokorelasi tidak ditemukan variabel yang menyimpang dari asumsi klasik, hal ini menunjukkan bahwa data yang tersedia telah memenuhi syarat untuk menggunakan model persamaan regresi linier berganda. Dari hasil analisis menunjukkan bahwa data LDR, NPL, dan BOPO secara parsial signifikan terhadap ROA.

4. Andy Setiawan, Bambang Hermanto (2017) Comparative study: determinant on banking profitability between buku 4 and buku 3 bank in Indonesia Hasil penelitian ini menunjukkan bahwa seluruh variabel independen berpengaruh signifikan secara bersama terhadap ROA dan ROE. Secara parsial NIM berpengaruh signifikan terhadap ROA dan ROE di BUKU 3 dan BUKU 4, sedangkan variabel lainnya memiliki pengaruh yang berbedabeda terhadap profitabilitas. Kemampuan prediksi dari variabel independen tersebut terhadap ROA adalah 64,7\% di bank BUKU 3 dan 90,4\% di bank BUKU 4. Sedangkan variabel independen memiliki kemampuan prediksi terhadap ROE sebesar 55,4\% di bank BUKU 3 dan 74,1\% di bank BUKU 4.

5. Farah Margaretha, Adisty Adisty.(2017) . Masalah dalam penelitian ini adalah pengaruh risiko likuiditas, rasio fasilitas kredit bersih terhadap total aset, rasio total investasi terhadap total aset, rasio total ekuitas terhadap aset, rasio fasilitas kredit bersih terhadap total deposito, rasio biaya terhadap pendapatan, dan ukuran bank terhadap pengembalian aset. Tujuan penelitian ini adalah untuk mengidentifikasi faktor-faktor yang mempengaruhi pengembalian aset bank yang terdaftar di Bursa Efek Indonesia dan Bursa Efek Hong Kong selama periode 2012-2015. Metodologi penelitian ini adalah regresi linier berganda yang diuji dengan menggunakan asumsi klasik. Sampel dalam penelitian ini adalah 27 Bank yang terdaftar di Bursa Efek Indonesia dan 13 Bank yang terdaftar di Bursa Efek Hong Kong selama periode 20122015. Temuan dan kontribusi dalam penelitian ini adalah risiko likuiditas, rasio total ekuitas terhadap aset, fasilitas kredit bersih terhadap total rasio simpanan, rasio biaya terhadap pendapatan, dan ukuran bank memiliki pengaruh terhadap pengembalian aset bank di Indonesia. Sementara itu, fasilitas kredit bersih terhadap rasio total aset dan total investasi terhadap total aset tidak memiliki pengaruh terhadap pengembalian aset bank di Indonesia. Risiko likuiditas, total rasio ekuitas terhadap aset, dan rasio biaya terhadap pendapatan memiliki pengaruh terhadap pengembalian aset bank di Hong Kong, sedangkan rasio fasilitas kredit terhadap total aset, rasio total investasi terhadap total aset, rasio fasilitas kredit terhadap total deposito, dan ukuran bank tidak memiliki pengaruh terhadap pengembalian aset bank di Hong Kong. Keterbatasan atau implikasi penelitian dalam penelitian ini adalah bagi manajemen perbankan untuk menggunakan informasi tersebut untuk mempertahankan atau bahkan meningkatkan profitabilitas bank,

6. Adhista Setyarini(2019), Hasil penelitian ini menunjukkan bahwa variabel NPL tidak mempengaruhi ROA. Variabel CAR, NIM, dan LDR berpengaruh positif signifikan terhadap ROA. Variabel BOPO berpengaruh negatif signifikan terhadap ROA. Kemampuan prediksi dari kelima variabel ini terhadap ROA adalah $63,6 \%$ dimana sisanya $36,4 \%$ dipengaruhi oleh faktor lain yang tidak dimasukkan ke dalam model penelitian.

7. Debby Andesfa, Erni Masdupi (2018) Effect of Financial Ratio on Profitability of Commercial Banks; a Systematic Literature Review, Penelitian ini dilatarbelakangi oleh pengaruh rasio keuangan terhadap profitabilitas bank komersial. Beberapa faktor rasio keuangan yang mempengaruhi kinerja bank adalah rasio kecukupan modal (CAR), rasio kredit macet (NPL), rasio pinjaman terhadap deposito (LDR) untuk profitabilitasnya. Tinjauan ini mencakup 26 artikel jurnal yang diterbitkan dari tahun 2000 hingga 2017 dan beberapa bulan 2012 . 26 artikel diklasifikasikan "profitabilitas" dan "Pengaruh Rasio Keuangan" bank komersial dalam bisnis menjadi tiga yang berbeda kategori: "rasio kecukupan modal (ROA)," "rasio kecukupan modal (CAR)," Pengaruh Rasio Keuangan "Non Performing Loan (NPL)," "rasio pinjaman terhadap deposito (LDR), ". Temuan mengungkapkan bahwa 
"Profitabilitas" adalah kategori yang paling sering telah dipertimbangkan dalam literatur. Ulasan ini menyediakan sumber untuk menemukan dampak bisnis dari situs jejaring sosial dan akan membantu mensimulasikan minat lebih lanjut daerah.

8. Zulkifli Z dan Rispa Eliza (2018) Determinan Net Interest Margin perbankan nasional: aplikasi model regresi data panel fixed effect. Penelitian bertujuan membuktikan secara empiris faktor penentu kinerja rasio net interest margin (NIM) perbankan yang tercatat di Bursa Efek Indonesia (BEI) selama periode 2005-2015 menggunakan metode regresi data panel fixed effect dengan sebelas bank yang terpilih sebagai sampel penelitian. Hasil penelitian menemukan bahwa faktor rasio NPL, LDR, ROA, SBI, dan Kurs secara signifikan berpengaruh terhadap kinerja rasio NIM. Dari variabel yang berpengaruh secara signifikan, variabel nilai tukar merupakan variabel yang paling dominan pengaruhnya, sementara variabel rasio NPL merupakan variabel yang pengaruhnya paling kecil. Seluruh variabel bebas, yang terdiri dari; CAR, NPL, LDR, BOPO, ROA, SBI, inflasi, dan kurs secara serentak mempengaruhi rasio NIM perbankan yang tercatat di Bursa Efek Indonesia (BEI) selama periode 2005-2015 secara signifikan. Secara individual, bank yang paling besar sensitivitasnya terhadap perubahan rasio NIM adalah Bank Internasional Indonesia Tbk (BII), sementara yang paling rendah sensitivitasnya adalah Bank Victoria Indonesia Tbk (BVI).

9. Hantono (2017) Effect of Capital Adequacy Ratio (CAR), Loan to Deposit Ratio (LDR) and Non Performing Loan (NPL) to Return On Assets (ROA) listed in banking in Indonesia stock exchange. Penelitian ini bertujuan untuk memverifikasi dan menganalisis pengaruh Capital Adequacy Ratio (CAR), Loan to Deposit Ratio (LDR), dan Non-Performing Loans (NPL) untuk Return on Asset di perusahaan perbankan terdaftar di Bursa Efek Indonesia 2010-2013. Populasi dalam penelitian ini adalah 41 perbankan perusahaan yang terdaftar di Bursa Efek Indonesia 2010-2013. Dari 41 perusahaan yang terdaftar, dipilih 26 perusahaan sampel menggunakan purposive sampling. Data yang digunakan dalam penelitian ini adalah data sekunder, oleh mengumpulkan informasi yang diperlukan dari idx 2010-2013. Metode tahun laporan keuangan yang digunakan untuk menganalisis hubungan antara variabel bebas dengan variabel terikat adalah berganda analisis regresi, dan uji asumsi.Hasil diskusi menunjukkan bahwa simultan independen variabel; Rasio Kecukupan Modal (CAR), Loan to Deposit Ratio (LDR), dan Non-Performing Pinjaman (NPL) dengan uji F, secara bersama- sama mempengaruhi Pengembalian Aset. Hasil sebagian dengan uji t, variabel Rasio Kecukupan Modal (CAR), Loan to Deposit Ratio (LDR), dan Non Performing Loans (NPL) efek pada Pengembalian Aset.

10. Anne Maria (2015) Penelitian ini bertujuan untuk mengidentifikasi pengaruh Capital Adequacy Ratio, Biaya Operasional terhadap Pendapatan Operasional, Margin Bunga Bersih, Rasio Setoran Pinjaman terhadap Return On Asset pada 10 bank teratas 2013 di Indonesia. Penelitian ini menggunakan pendekatan kuantitatif dan metode pengumpulan data. 10 bank teratas adalah PT Bank Mandiri (Persero), Tbk, PT Bank Rakyat Indonesia (Persero), Tbk, PT Bank Central Asia, Tbk, PT Bank Negara Indonesia (Persero), Tbk, PT Bank CIMB Niaga, Tbk, PT Bank Danamon Indonesia, Tbk, PT Pan Indonesia Bank, Tbk, PT Bank Permata, Tbk, PT Bank Internasional Indonesia, Tbk, dan PT Bank Tabungan Negara (Persero) pada periode 2007-2011. Hasil penelitian ini menunjukkan bahwa Biaya Operasional terhadap Pendapatan Operasional berpengaruh negatif dan signifikan terhadap Return On Asset. Margin Bunga Bersih berpengaruh positif dan signifikan terhadap Return On Asset. Rasio Kecukupan Modal dan Rasio Setoran Pinjaman berpengaruh positif dan tidak signifikan terhadap ROA. Non Performing Loan berpengaruh negatif dan tidak signifikan terhadap Return On Asset.

11. Pedro Soares dam Muhammad Yunanto (2018). Penelitian ini bertujuan untuk mengetahui pengaruh Non-Performing Loan (NPL), Capital Adequacy Ratio (CAR), Loan to Deposit Ratio (LDR), Operating Expense Ratio (OER) dan Net Interest Margin (NIM) terhadap Return on Assets perbankan (ROA). Populasi penelitian ini adalah 10 Bank Umum berdasarkan aset terbesar pada periode 2011-2016 tahun dengan menggunakan metode Analisis Regresi Linier Berganda melalui SPSS 20. Teknik pengambilan sampel adalah purposive sampling; sampling disengaja yang ada di sesuai dengan persyaratan sampel. Hasil tes menyatakan bahwa variabel NPL memiliki positif dan pengaruh tidak signifikan terhadap ROA, variabel CAR tidak berpengaruh terhadap ROA, variabel LDR negatif dan pengaruh signifikan terhadap ROA, variabel PER berpengaruh negatif dan tidak signifikan terhadap ROA, dan Variabel NIM berpengaruh positif dan tidak signifikan terhadap ROA

Para peneliti terdahulu pada umumnya menggunakan metode yang sama dengan menggunakan uji statistik dengan SPSS dengan objek penelitian sebagian bank sebagai sample bank atau kelompok bank tertentu saja, Hasil penelitian pada umumnya rasio CAR, BOPO, 
NIM, LDR, dan NPL berpengaruh terhadap ROA. Penelitian yang akan dilakukan sama menggunakan SPSS, namun Bank yang diteliti adalah seluruh bank umum konvensional untuk pembanding kondisi semua bank populasi, kategori dikelompokan berdasarkan kategori kepemilikan, variabel yang digunakan adalah rasio-rasio yang digunakan untuk menilai tingkat kesehatan bank. Penelitian ini juga untuk menguji hasil penelitian sebelumnya atau dapat melengkapi ataupun dapat mempertegas penelitian sebelumnya. Penelitian ini menggunakan data sekunder dalam kurun waktu 5(Lima Tahun) periode tahun 2014 sampai dengan tahun 2018 dan data variabel berupa rasio-rasio diambil dari satu sumber yaitu laporan Statistik Perbankan Indonesia yang dikeluarkan Otoritas Jasa Keuangan(OJK)

\section{Pengujian Asumsi Klasik}

Karena data yang digunakan adalah data sekunder, maka untuk menentukan ketepatan model perlu dilakukan pengujian atas beberapa asumsi klasik yang mendasari model regresi. Pengujian asumsi klasik yang digunakan dalam penelitian ini meliputi uji, normalitas, multikolinearitas, heteroskedastisitas dan autokorelasi. Masing-masing pengujian asumsi klasik tersebut secara rinci dapat dijelaskan sebagai berikut:

Uji normalitas bertujuan untuk menguji apakah dalam model regresi, variabel pengganggu atau residual memiliki distribusi normal. Seperti diketahui bahwa uji $\mathrm{t}$ dan $\mathrm{F}$ mengasumsikan bahwa nilai residual mengikuti distribusi normal. Kalau asumsi ini dilarang maka uji statistik menjadi tidak valid untuk jumlah sampel kecil. Ada dua cara untuk mendeteksi apakah residual berdistribusi normal atau tidak yaitu dengan analisis grafik dan uji statistik (Imam Ghozali, 2011).

Uji multikolinieritas bertujuan untuk menguji apakah model regresi ditemukan adanya korelasi antar variabel bebas (independen). Model regresi yang baik seharusnya tidak terjadi korelasi di antara variabel independen. Jika variabel independen saling berkorelasi, maka variabel-variabel ini tidak ortogonal. Variabel ortogonal adalah variabel independen yang nilai korelasi antar sesama variabel independen sama dengan nol (Imam Ghozali, 2011).

Uji heteroskedastisitas bertujuan untuk menguji apakah dalam model regresi terjadi ketidaksamaan variance dari residual satu pengamatan ke pengamatan yang lain. Jika variance dari residual satu pengamatan ke pengamatan lain tetap, maka disebut Homoskedastisitas dan jika berbeda disebut Heteroskedastisitas. Model regresi yang baik adalah yang Homoskedastisitas atau tidak terjadi Heteroskedastisitas. Kebanyakan data cross section mengandung situasi heteroskedastis karena data ini menghimpun data yang mewakili berbagai ukuran (kecil, sedang dan besar) (Imam Ghozali, 2011).

Uji autokorelasi bertujuan menguji apakah dalam model regresi linier ada korelasi antara kesalahan pengganggu pada periode $\mathrm{t}$ dengan kesalahan pengganggu pada periode t-1 (sebelumnya). Jika terjadi korelasi, maka dinamakan ada problem autokorelasi. Autokorelasi muncul karena observasi yang berurutan sepanjang waktu berkaitan satu sama lainnya. Hal ini sering ditemukan pada data runtut waktu (time series) karena "gangguan" pada seseorang individu / kelompok cenderung mempengaruhi gangguan pada individu / kelompok yang sama pada periode berikutnya.

Pada data cross section (silang waktu), masalah autokorelasi relatif jarang terjadi karena gangguan pada observasi yang berbeda berasal dari individu. Kelompok yang berbeda. Model regresi yang baik adalah regresi yang bebas dari autokorelasi (Imam Ghozali, 2011).

Pengujian Hipotesis, Ketepatan fungsi regresi sampel dalam menaksir nilai aktual dapat diukur dari goodness of fitnya. Secara statistik, setidaknya ini dapat diukur dari nilai koefisien determinasi, nilai statistik F dan nilai statistik t. Perhitungan statistik disebut signifikan secara statistik apabila nilai uji statistiknya berada dalam daerah kritis (daerah dimana Ho ditolak). Sebaliknya disebut tidak signifikan bila nilai uji statistiknya berada dalam daerah dimana Ho diterima (Ghozali, 2011).

Koefisien determinasi $\left(\mathrm{R}^{2}\right)$ pada intinya mengukur seberapa jauh kemampuan model dalam menerangkan variasi variabel dependen. Nilai koefisien determinasi adalah antara nol dan satu. Nilai $\mathrm{R}^{2}$ yang kecil berarti kemampuan variabel-variabel independen dalam menjelaskan variasi variabel dependen amat terbatas. Nilai yang mendekati satu berarti variabel-variabel independen memberikan hampir semua informasi yang dibutuhkan untuk memprediksi variasi variabel dependen. Secara umum koefisien determinasi untuk data silang (cross section) relatif rendah karena adanya variasi yang besar antara masing-masing pengamatan, sedangkan untuk data runtun waktu (time series) biasanya mempunyai nilai koefisien determinasi yang tinggi (Imam Ghozali, 2011).

Uji statistik $F$ pada dasarnya menunjukkan apakah semua variabel independen atau bebas yang dimasukkan dalam model mempunyai pengaruh secara bersama-sama terhadap variabel dependen/terikat. Hipotesis nol (Ho) yang hendak diuji adalah apakah semua parameter dalam model sama dengan nol, atau:

Ho: $\mathrm{b} 1=\mathrm{b} 2=\ldots \ldots . .=\mathrm{bk}=0 \quad \rightarrow(1)$

artinya, apakah semua variabel independen bukan merupakan penjelas yang signifikan terhadap variabel dependen. Hipotesis alternatifnya (HA) tidak semua parameter secara simultan sama dengan nol, atau:

HA: $\mathrm{b} 1 \neq \mathrm{b} 2 \neq \ldots \ldots . \neq \mathrm{bk} \neq 0 \quad \rightarrow(2)$

artinya, semua variabel independen secara simultan merupakan penjelas yang signifikan terhadap variabel 
dependen (Imam Ghozali, 2011). Untuk menguji hipotesis ini digunakan statistik $\mathrm{F}$ dengan kriteria pengambilan keputusan sebagai berikut:

a. quick look: bila nilai $\mathrm{F}$ lebih besar daripada 4 maka Ho dapat ditolak pada derajat kepercayaan $5 \%$. Dengan kata lain kita menerima hipotesis alternatif, yang menyatakan bahwa semua variabel independen secara serentak dan signifikan mempengaruhi variabel dependen.

b. Membandingkan nilai $\mathrm{F}$ hasil perhitungan dengan nilai $F$ menurut tabel. Bila nilai $F$ hitung lebih besar daripada nilai $\mathrm{F}$ tabel, maka Ho ditolak dan menerima HA.

Uji statistik t pada dasarnya menunjukkan seberapa jauh pengaruh satu variabel penjelas/independen secara individual dalam menerangkan variasi variabel dependen. Hipotesis nol (Ho) yang hendak diuji adalah apakah suatu parameter (bi) sama dengan nol, atau:

Ho: bi $=0 \rightarrow(3)$

artinya apakah suatu variabel independen bukan merupakan penjelas yang signifikan terhadap variabel dependen. Hipotesis alternatifnya (HA) parameter suatu variabel tidak sama dengan nol, atau:

HA: $b i \neq 0 \rightarrow(4)$

artinya, variabel tersebut merupakan penjelas yang signifikan terhadap variabel dependen (Imam Ghozali, 2011).

Cara melakukan uji t adalah sebagai berikut:

a. Quick look: bila jumlah degree of freedom (df) adalah 20 atau lebih, dan derajat kepercayaan sebesar 5\%, maka Ho yang menyatakan bi $=0$ dapat ditolak bila nilai t lebih besar dari 2 (dalam nilai absolut). Dengan kata lain kita menerima hipotesis alternatif, yang menyatakan bahwa suatu variabel independen secara individual mempengaruhi variabel dependen.

b. Membandingkan nilai statistik t dengan titik kritis menurut tabel. Apabila nilai statistik $\mathrm{t}$ hasil perhitungan lebih tinggi dibandingkan nilai t tabel, kita menerima hipotesis alternatif yang menyatakan bahwa suatu variabel independen secara individual mempengaruhi variabel dependen.

\section{METODE PENELITIAN}

\section{Jenis dan Sumber Data}

Jenis data yang digunakan dalam penelitian ini adalah data sekunder. Data berupa rasio-rasio keuangan bank hasil olahan Otoritas Jasa Keuangan terhadap laporan keuangan bank. Peneliti menggunakan data periode tahun 2014-2018.

\section{Populasi dan Prosedur Penentuan Sampel.}

Populasi dalam penelitian ini adalah bank persero yang beroperasi di Indonesia. Teknik penentuan sampling adalah sampling jenuh atau sensus yaitu dimana semua anggota populasi digunakan sebagai sampel yang berarti sampel yang digunakan sama dengan populasi. Sampel seluruhnya diambil dari 6 kelompok bank Umum Konvensional yaitu Kelompok Bank Persero. Bank Umum Swasta Nasional (BUSN) Devisa, Bank Umum Swasta Nasional (BUSN) NON Devisa, Bank Pembangunan Daerah (BPD), Bank Campuran, dan Bank Asing.

\section{Prosedur Pengumpulan Data}

Metode pengumpulan data yang digunakan dengan cara non participant observation, yaitu mencatat atau mengunduh data dari Laporan publikasi pada website Otoritas Jasa Keruangan (OJK).

\section{Definisi Operasional Variabel}

Variable-variabel yang digunakan dalam penelitian ini adalah:

Variabel Independen dalam Penelitian ini adalah CAR, BOPO/REO. NIM, LDR, dan NPL, sedangkan Variabel dependen berupa kinerja perbankan yang diukur dengan Return On Assets. ROA pada bentuk yang paling sederhana dihitung sebagai laba dibagi aktiva. ROA dapat dipisahkan menjadi komponen yang memiliki makna relatif terhadap penjualan. Hal ini dilakukan karena rasio komponen ini berguna bagi analisis kinerja perusahaan. Penjualan merupakan kriteria penting untuk menilai profitabilitas perusahaan dan merupakan indikator utama atas aktivitas perusahaan. ROA yang digunakan dalam penelitian mengacu pada Surat Edaran Otoritas Jasa Keuangan No.14/SEOJK.03/2017 tentang Penilaian Tingkat Kesehatan Bank Umum dimana didefinisikan sebagai berikut:

\section{Kerangka Konseptual}

Sebagai dasar untuk merumuskan hipotesis, berikut kerangka pikir teoritis yang menunjukkan pengaruh variabel CAR, NIM, LDR, BOPO dan NPL terhadap ROA: 


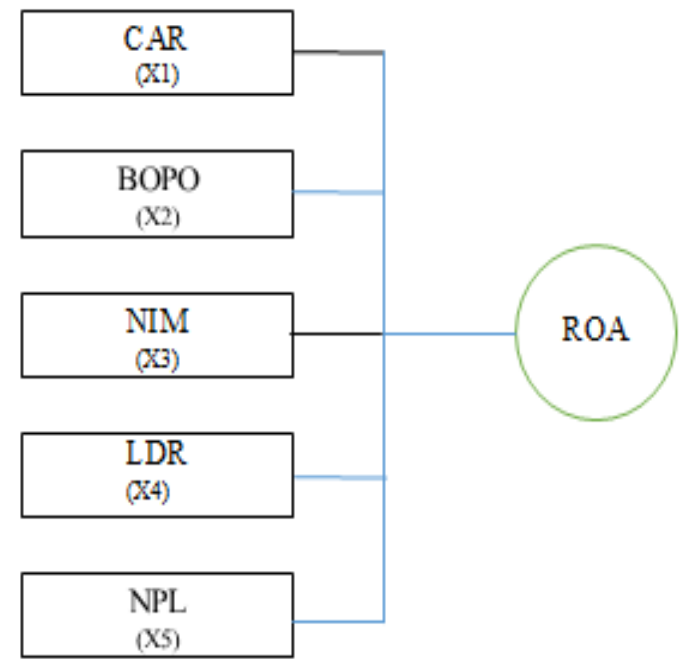

Gambar 1 Kerangka Pikir Teoritis

\section{Hipotesis Penelitian}

Dari landasan konseptual, tinjauan pustaka, dan kerangka pikir yang telah diuraikan, dapat disusun beberapa hipotesis penelitian sebagai berikut.

\section{H1: CAR (Capital Adequacy Ratio) berpengaruh positif terhadap ROA.}

H2: BOPO / ROE berpengaruh negatif terhadap ROA.

H3: NIM (Net Interest Margin) berpengaruh positif terhadap ROA.

H4: LDR (Loan to Deposit Ratio) berpengaruh negatif terhadap ROA.

H5: (NPL) Non Performing Loan berpengaruh negatif terhadap ROA.

\section{Teknik Analisis}

Penelitian ini menggunakan lebih dari dua variabel independen, sehingga untuk menjelaskan hubungan dan seberapa besar pengaruh variabel- variabel independen terhadap variabel dependen, digunakan model analisis regresi linier berganda. Regresi berganda berguna untuk meramalkan pengaruh dua atau lebih variabel prediktor terhadap satu variabel kriterium atau untuk membuktikan ada atau tidaknya hubungan fungsional antara dua buah variabel bebas (X) atau lebih dengan sebuah variabel terikat (Y) (Usman, 2003). Analisis regresi brganda dalam penelitian ini digunakan untuk mengetahui pengaruh Capital Adequacy Ratio (CAR), Biaya Operasional terhadap Pendapatan Operasional (BOPO), Net Interest Margin (NIM), Loan to Deposit Ratio (LDR), dan Non Performing Loan (NPL) terhadap Return on Assets (ROA) pada Bank Umum Konvensional Indonesia periode 2012-2018.

Formulasi persamaan regresi berganda sendiri adalah sebagai berikut:

$\mathrm{Y}=\alpha+\beta 1 \mathrm{X} 1+\beta 2 \mathrm{X} 2+\beta 3 \mathrm{X} 3+\beta 4 \mathrm{X} 4+\beta 5 \mathrm{X} 5+\mathrm{e}$

Keterangan:

$$
\begin{array}{ll}
\mathrm{Y} & =\text { Return on Assets } \\
\alpha & =\text { konstanta } \\
\beta 1-\beta 5 & =\text { koefisien regresi } \\
\mathrm{X} 1 & =\text { Capital Adequacy Ratio } \\
\mathrm{X} 2 & =\text { Non Performing Loan } \\
\mathrm{X} 3 & =\text { Biaya Operasional terhadap Pendapatan } \\
\mathrm{X} 4 & =\text { Loan to Deposit Ratio } \\
\mathrm{X} 5 & =\text { Net Interest Margin } \\
\mathrm{e} & =\text { error term }
\end{array}
$$

\section{HASIL PEMBAHASAN}

\section{Deskripsi Obyek Penelitian}

Objek penelitian ini adalah Bank Umum Konvensional berbagai kategori yang terdiri dari Bank Persero, Bank Umum Swasta Nasional (BUSN) Devisa, Bank Umum Swasta Nasional (BUSN) Non Devisa, Bank Pembangunan Daerah (BPD), Bank Campuran, dan Bank Asing.

\section{Deskripsi Sampel Penelitian}

Pada penelitian ini menggunakan sampel perusahaan Bank Umum Konvensional di Indonesia pada tahun 2014-2018. Adapun distribusi sampel yang digunakan adalah sebagai berikut: 
Tabel 2 Perkembangan Rasio Bank Umum Konvensional Periode Tahun 2014 - 2018

\begin{tabular}{|c|c|c|c|c|c|c|c|}
\hline Nama Bank & Tahun & $\begin{array}{c}\text { CAR } \\
\text { (X1) }\end{array}$ & $\begin{array}{c}\text { BOPO } \\
\text { (X2) }\end{array}$ & $\begin{array}{l}\text { NIM } \\
\text { (X3) }\end{array}$ & $\begin{array}{c}\text { LDR } \\
\text { (X4) }\end{array}$ & $\begin{array}{l}\text { NPL } \\
\text { (X5) }\end{array}$ & ROA $(\mathbf{Y})$ \\
\hline \multirow{5}{*}{ BANK PERSERO } & 2014 & 17,08 & 69,57 & 5,11 & 83,73 & 1,94 & 3,75 \\
\hline & 2015 & 19,31 & 72,58 & 6,19 & 88,58 & 2,33 & 3,31 \\
\hline & 2016 & 21,05 & 78,41 & 6,33 & 88,69 & 2,86 & 2,77 \\
\hline & 2017 & 21,09 & 72,58 & 5,95 & 88,67 & 2,50 & 2,98 \\
\hline & 2018 & 20,88 & 71,24 & 5,70 & 92,83 & 2,27 & 3,08 \\
\hline \multirow{5}{*}{ BUSN DEVISA } & 2014 & 16,42 & 80,70 & 3,78 & 85,66 & 2,24 & 2,13 \\
\hline & 2015 & 18,45 & 84,98 & 5,07 & 87,55 & 2,40 & 1,75 \\
\hline & 2016 & 20,39 & 84,58 & 5,27 & 84,83 & 3,10 & 1,65 \\
\hline & 2017 & 21,06 & 79,93 & 4,87 & 86,06 & 2,75 & 2,04 \\
\hline & 2018 & 21,21 & 79,72 & 4,72 & 90,63 & 2,57 & 2,20 \\
\hline \multirow{5}{*}{ BUSN NON DEVISA } & 2014 & 23,07 & 86,31 & 7,02 & 87,81 & 2,17 & 2,16 \\
\hline & 2015 & 22,15 & 96,03 & 3,97 & 81,12 & 2,35 & 0,47 \\
\hline & 2016 & 25,91 & 91,78 & 5,78 & 88,37 & 3,82 & 0,98 \\
\hline & 2017 & 28,34 & 90,32 & 5,56 & 92,49 & 4,25 & 1,12 \\
\hline & 2018 & 27,63 & 88,70 & 5,94 & 95,02 & 2,47 & 1,34 \\
\hline \multirow{5}{*}{ BPD } & 2014 & 17,79 & 78,08 & 6,65 & 89,73 & 3,45 & 2,68 \\
\hline & 2015 & 20,61 & 79,57 & 6,66 & 92,19 & 3,67 & 2,40 \\
\hline & 2016 & 21,69 & 78,08 & 7,07 & 93,65 & 3,30 & 2,58 \\
\hline & 2017 & 21,65 & 78,65 & 6,42 & 87,62 & 3,23 & 2,40 \\
\hline & 2018 & 22,05 & 77,88 & 6,32 & 88,86 & 2,68 & 2,38 \\
\hline \multirow{5}{*}{ BANK CAMPURAN } & 2014 & 19,14 & 78,49 & 2,40 & 123,61 & 2,28 & 2,11 \\
\hline & 2015 & 20,39 & 87,55 & 3,38 & 132,77 & 2,97 & 1,01 \\
\hline & 2016 & 21,01 & 88,89 & 3,63 & 129,01 & 2,40 & 1,34 \\
\hline & 2017 & 21,71 & 85,02 & 3,69 & 129,02 & 1,64 & 1,43 \\
\hline & 2018 & 21,76 & 91,03 & 3,25 & 138,67 & 1,63 & 1,13 \\
\hline \multirow{5}{*}{ BANK ASING } & 2014 & 44,81 & 79,30 & 2,12 & 140,04 & 1,22 & 3,08 \\
\hline & 2015 & 46,46 & 92,69 & 3,59 & 131,49 & 2,11 & 1,68 \\
\hline & 2016 & 48,94 & 87,66 & 3,90 & 122,38 & 1,89 & 2,68 \\
\hline & 2017 & 53,09 & 89,94 & 3,72 & 122,33 & 1,44 & 2,63 \\
\hline & 2018 & 47,87 & 88,43 & 3,76 & 138,99 & 1,71 & 2,67 \\
\hline Rata-rata & & 25,77 & 82,96 & $\mathbf{4 , 9 3}$ & 102,75 & 2,52 & 2,13 \\
\hline
\end{tabular}

Sumber: Laporan Statistik Perbankan Indonesia OJK

Berdasarkan perhitungan melalui komputer dengan menggunakan program SPSS, diperoleh hasil statistik deskriptif dari Bank Umum Konvensional sebagai berikut:

Tabel 3 Descriptive Statistics

\begin{tabular}{|c|c|c|c|c|c|}
\hline & $\mathbf{N}$ & Minimum & Maximum & Mean & Std. Deviation \\
\hline CAR & 30 & 16,42 & 53,09 & 25,7670 & 10,59745 \\
\hline BOPO & 30 & 69,57 & 96,03 & 82,9563 & 6,92117 \\
\hline NIM & 30 & 2,12 & 7,07 & 4,9273 & 1,40528 \\
\hline LDR & 30 & 81,12 & 140,04 & 102,7467 & 20,74475 \\
\hline NPL & 30 & 1,22 & 4,25 & 2,5213 & ,72198 \\
\hline $\mathrm{ROA}$ & 30 & ,47 & 3,75 & 2,1310 & ,79207 \\
\hline Valid N (listwise) & 30 & & & & \\
\hline
\end{tabular}


Dari tabel 3 dapat dilihat bahwa rata-rata Capital Adequacy Ratio (CAR) sebesar 25,7670. Perusahaan yang memiliki nilai CAR terendah yaitu BUSN Devisa (lihat Tabel 1) dengan nilai sebesar 16,42 Sedangkan perusahaan dengan nilai CAR tertinggi adalah Bank asing yaitu sebesar 53,09\%. Rata-rata nilai CAR Bank Umum Konvensional pada tahun 2014-2018 jauh lebih besar dibanding dengan nilai CAR yang disyaratkan oleh Otoritas Jasa Keuangan yaitu $12 \%$.

Rata-rata Biaya Operasional dibanding dengan Pendapatan Operasional (BOPO) Bank Umum Konvensional Periode 2014-2018 sebesar 82,9563. Bank yang mempunyai nilai BOPO terendah yaitu Bank Persero (lihat Tabel 1) dengan nilai sebesar 69,57 Sedangkan bank dengan nilai BOPO tertinggi yaitu BUSN Non Devisa dengan nilai sebesar 96,03.

Rata-rata Net Interest Margin (NIM) Bank Umum Konvensional periode tahun 2014-2018 sebesar 4,9273. Bank yang mempunyai nilai NIM terendah yaitu Bank Asing (lihat Tabel 1) dengan nilai sebesar 2,12. Sedangkan bank dengan nilai NIM tertinggi yaitu BPD dengan nilai sebesar 7,07.

Rata-rata Loan to Deposit Ratio (LDR) dari Bank Umum Konvensional periode 2014-2018 sebesar 102,7467. Bank yang memiliki nilai LDR tertinggi yaitu Bank asing (lihat Tabel 1) dengan nilai sebesar 140,04. Sedangkan bank yang memiliki nilai LDR terendah yaitu BUSN Non Devisa dengan nilai sebesar 81,12 .

Rata-rata Non Performing Loan (NPL) dari Bank Umum Konvensional periode tahun 2014-2018 sebesar 2,5213. Hal ini menunjukkan bahwa nilai NPL pada tahun tersebut masih dalam batas maksimum NPL yang disyaratkan oleh Otoritas Jasa Keuangan yaitu sebesar 5\%. Bank yang mempunyai nilai NPL terendah yaitu Bank Asing (lihat Tabel 1) dengan nilai sebesar 1,22\%. Sedangkan bank dengan nilai NPL tertinggi yaitu Bank Swasta Nasional Non Devisa dengan nilai sebesar 4,25 $\%$

Rata-rata Return On Assets (ROA) dari Bank Umum Konvensional periode tahun 2012-2018 sebesar 2,1310. Bank yang mempunyai nilai ROA terendah yaitu BUSN Non Devisa (lihat Tabel 1) dengan nilai 0,47. Sedangkan bank dengan nilai ROA tertinggi yaitu Bank Persero dengan nilai sebesar 3,75.

\section{Uji Asumsi Klasik}

\section{Uji Normalitas}

Uji normalitas bertujuan untuk menguji apakah dalam model regresi, variabel terikat dan variabel bebas keduanya mempunyai distribusi normal ataukah tidak. Model regresi yang baik adalah memiliki distribusi data normal atau mendekati normal. Untuk menguji apakah distribusi data normal atau tidak, salah satu cara termudah untuk melihat normalitas adalah melihat histogram yang membandingkan antara data observasi dengan distribusi yang mendekati distribusi normal. Namun demikian dengan hanya melihat histogram hal ini bisa menyesatkan khususnya untuk jumlah sampel yang kecil. Metode yang lebih handal adalah dengan melihat Normal Probability Plot yang membandingkan distribusi kumulatif dari data sesungguhnya dengan distribusi kumulatif dari distribusi normal. Distribusi normal akan membentuk satu garis lurus diagonal, dan ploting data akan dibandingkan dengan garis diagonal. Jika distribusi data adalah normal, maka garis yang menggambarkan data sesungguhnya akan mengikuti garis diagonalnya. (Ghozali, 2011)

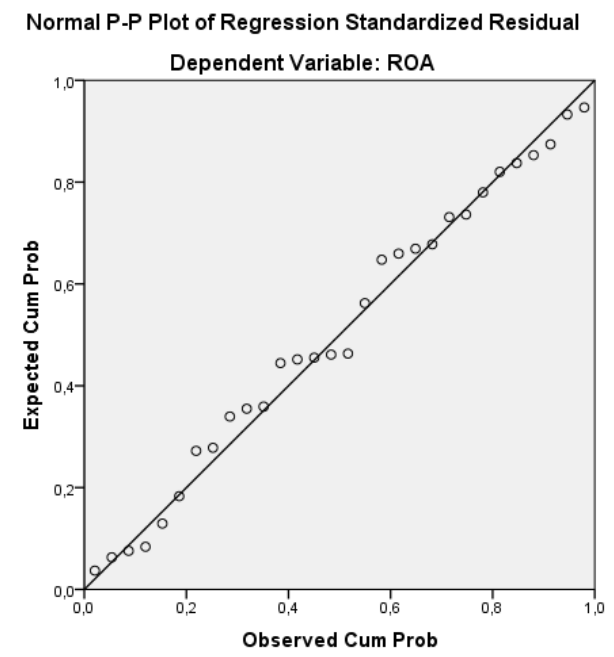

Gambar 2 hasil pengujian SPSS

Berdasarkan hasil pengujian SPSS, Normal Probability Plot yang terbentuk adalah sebagai berikut:

Jika dilihat berdasarkan grafik di atas, maka data dari semua data berdistribusi normal. Hal ini karena semua data menyebar mengikuti garis Normalitas.

\section{Multikolinieritas}

Menurut Imam Ghozali (2011) multikolinearitas dapat juga dilihat dari nilai Tolerance dan lawannya Variance Inflation Factor (VIF). Kedua ukuran ini menunjukkan setiap variabel bebas manakah yang dijelaskan oleh variabel bebas lainnya. Dalam pengertian sederhana setiap variabel bebas menjadi variabel terikat dan diregres terhadap variabel bebas lainnya. Tolerance mengukur variabilitas variabel bebas yang terpilih yang tidak dapat dijelaskan oleh variabel bebas lainnya. Jadi nilai tolerance rendah sama dengan nilai VIF tinggi (karena VIF $=1 /$ tolerance) dan menunjukkan

adanya kolinearitas yang tinggi. Nilai cut off yang umum dipakai adalah nilai tolerance di atas 0,10 atau sama dengan nilai VIF di bawah 10. Setiap analisa harus menentukan tingkat kolinearitas yang masih dapat ditolerir. 
Tabel 4 Hasil Multikolinearitas

\begin{tabular}{|c|c|c|c|c|c|c|c|c|}
\hline \multicolumn{9}{|c|}{ Coefficients $^{\mathrm{a}}$} \\
\hline \multirow{2}{*}{\multicolumn{2}{|c|}{ Model }} & \multirow{2}{*}{$\begin{array}{l}\text { Unstandardized } \\
\text { B }\end{array}$} & Coefficients & \multirow{2}{*}{$\begin{array}{c}\text { Standardized } \\
\text { Coefficients } \\
\text { Beta }\end{array}$} & \multirow[b]{2}{*}{$\mathrm{t}$} & \multirow[b]{2}{*}{ Sig. } & \multicolumn{2}{|c|}{ Collinearity Statistics } \\
\hline & & & Std. Error & & & & Tolerance & VIF \\
\hline \multirow[t]{6}{*}{1} & (Constant) & 10,211 & ,721 & & 14,161 & ,000 & & \\
\hline & CAR &, 041 & ,005 & ,544 & 8,033 & ,000 & ,538 & 1,860 \\
\hline & BOPO &,- 110 & 007 &,- 957 & $-15,546$ & ,000 & ,650 & 1,539 \\
\hline & NIM & ,121 & ,049 & ,215 & 2,460 & ,021 & ,324 & 3,089 \\
\hline & LDR &,- 001 & ,003 &,- 025 &,- 290 & ,774 &, 330 & 3,034 \\
\hline & NPL &,- 214 & ,078 &,- 195 & $-2,733$ &, 012 & ,484 & 2,067 \\
\hline
\end{tabular}

a. Dependent Variable: ROA

Hasil Analisis di atas terlihat untuk kelima variabel independent CAR, BOPO, NIM, LDR, NPL, angka VIF kurang dari 10 dan nilai tolerance di atas 0,10 . Dengan demikian dapat disimpulkan model regresi tersebut tidak terdapat problem multikolinearitas.

\section{Uji Heteroskedastisitas}

Korelasi adanya heteroskedastisitas adalah biasnya varians sehingga uji signifikan menjadi tidak valid, dengan adanya pengaruh-pengaruh variabel individu yang sulit dipisahkan.

Untuk mengetahui ada tidaknya heteroskedastisitas antar variabel independen dapat dilihat dari grafik plot antara nilai prediksi variabel terikat dengan residualnya. Adapun grafik hasil pengujian heteroskedastisitas dapat dilihat di bawah ini.

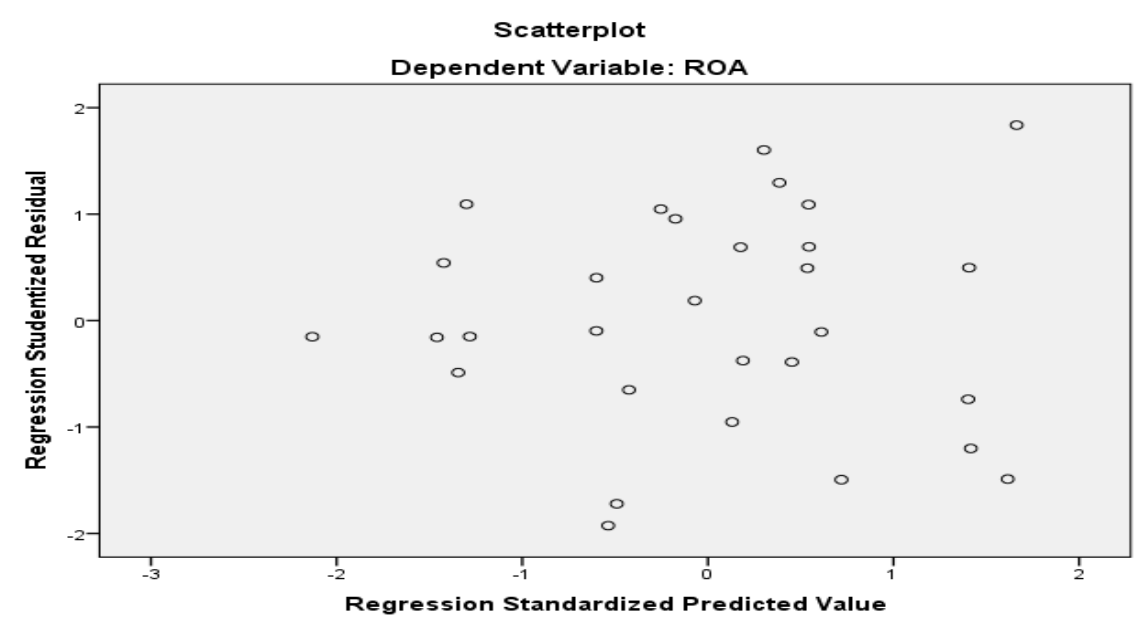

\section{Gambar 3 Uji Heteroskedastisitas}

Berdasarkan grafik tersebut dapat diketahui bahwa data (titik-titik) menyebar secara merata di atas dan di bawah garis nol, tidak berkumpul di satu tempat, serta tidak membentuk pola tertentu sehingga dapat disimpulkan bahwa pada uji regresi ini tidak terjadi problem heteroskedastisitas.

\section{Uji Autokorelasi}

Autokorelasi pada model regresi artinya ada korelasi antar anggota sampel yang diurutkan berdasarkan waktu saling berkorelasi. Untuk mengetahui adanya autokorelasi dalam suatu model regresi dilakukan melalui pengujian terhadap nilai uji Durbin Watson (Uji DW). Dengan ketentuan sebagai berikut:

Tabel 5 Pengambilan Keputusan Ada dan Tidaknya Autokorelasi

\begin{tabular}{lll}
\hline Ho (Hipotesis nol) & Keputusan & Jika \\
\hline Tidak ada autokorelasi positif & Tolak & $0<\mathrm{d}<\mathrm{dl}$ \\
Tidak ada autokorelasi positif & No decision & $\mathrm{dl} \leq \mathrm{d} \leq \mathrm{du}$ \\
Tidak ada autokorelasi negatif & Tolak & $4-\mathrm{dl}<\mathrm{d}<4$ \\
Tidak ada autokorelasi negatif & No decision & $4-\mathrm{du} \leq \mathrm{d} \leq 4 \mathrm{dl}$ \\
Tidak ada autokorelasi positif atau negatif & Terima & $\mathrm{du}<\mathrm{d}<4-\mathrm{du}$ \\
\hline Sub
\end{tabular}


Tabel 6 Hasil Uji Autokorelasi

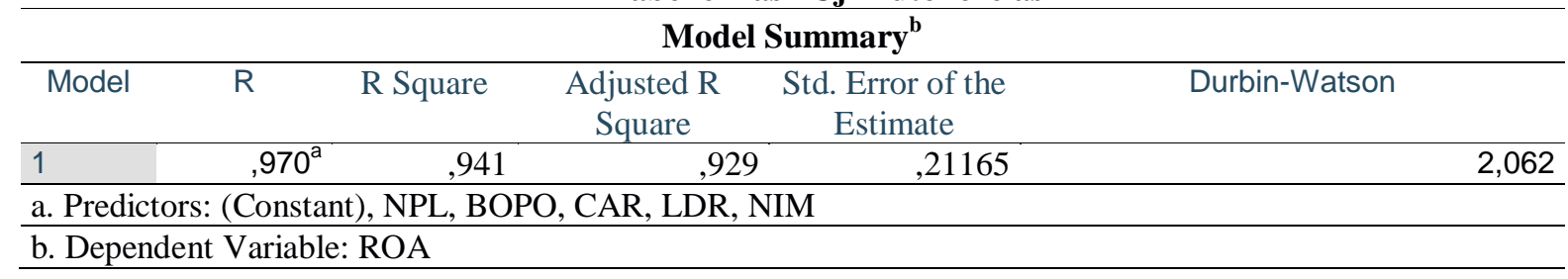

Menurut Imam Gozali (2011:111) Tidak ada Gejala Autokorelasi, jika nilai Durbin Watson terletak antara $\mathrm{du}<\mathrm{dw}<4-$ du. Pada uji regresi autokorelasi menghasilkan nilai Durbin-Watson sebesar 2,062, du $($ dari tabel DW $)=1.781,4-\mathrm{du}=2,219$, disimpulkan bahwa tidak terjadi autokorelasi, karena du $(1,781)$ $<2,062<4-$ du $(2.219)$

\section{Uji Regresi Linier Berganda}

Analisis statistik yang digunakan dalam penelitian ini yaitu regresi linier berganda. Analisis ini digunakan untuk mengetahui besarnya pengaruh variabel-variabel bebas (independent) yaitu CAR, BOPO, NIM, LDR, dan NPL terhadap variabel terikat (dependent) yaitu ROA. Besarnya pengaruh variabel independen (CAR, BOPO, NIM, LDR, dan NPL) dengan variabel dependen (ROA) secara bersama-sama dapat dihitung melalui suatu persamaan regresi berganda.

Berdasarkan perhitungan melalui komputer dengan menggunakan program SPSS (Release 24) diperoleh hasil regresi sebagai berikut:

Tabel 7 Ringkasan Hasil Estimasi Regresi CAR, BOPO, NIM, LDR DAN NPL Coefficients $^{\mathrm{a}}$

\begin{tabular}{|c|c|c|c|c|c|c|c|c|}
\hline \multirow{2}{*}{\multicolumn{2}{|c|}{ Model }} & \multicolumn{2}{|c|}{$\begin{array}{l}\text { Unstandardized } \\
\text { Coefficients }\end{array}$} & \multirow{2}{*}{$\begin{array}{c}\text { Standardized } \\
\text { Coefficients } \\
\text { Beta }\end{array}$} & \multirow[t]{2}{*}{$\mathrm{t}$} & \multirow[t]{2}{*}{ Sig. } & \multicolumn{2}{|c|}{ Collinearity Statistics } \\
\hline & & $\mathrm{B}$ & Std. Error & & & & Tolerance & VIF \\
\hline \multirow[t]{6}{*}{1} & (Constant) & 10,211 &, 721 & & 14,161 & ,000 & & \\
\hline & CAR & ,041 &, 005 &, 544 & 8,033 &, 000 & ,538 & 1,860 \\
\hline & BOPO &,- 110 & ,007 &,- 957 & $-15,546$ &, 000 & ,650 & 1,539 \\
\hline & NIM & ,121 & ,049 &, 215 & 2,460 &, 021 & ,324 & 3,089 \\
\hline & LDR &,- 001 & ,003 &,- 025 &,- 290 &, 774 & ,330 & 3,034 \\
\hline & NPL &,- 214 & 078 &,- 195 & $-2,733$ &, 012 & , 484 & 2,067 \\
\hline
\end{tabular}

Dari hasil analisis dengan program SPSS tersebut, maka dapat diketahui persamaan regresi yang terbentuk. Adapun persamaan regresi linier yang terbentuk adalah:

$Y=10,211+0,041 X 1-0,110 \times 2+0,121 \times 3-0,001 X 4-0,214 X 5 \rightarrow(6)$

Dari hasil analisis dapat diketahui bahwa variabel bebas yang paling berpengaruh adalah variabel NPL dengan koefisien -0,214. Kemudian diikuti oleh variabel NIM dengan koefisien 0,121, BOPO dengan koefisien 0,110, CAR dengan koefisien sebesar -0,041 dan LDR dengan koefisien sebesar -0,001. Sedangkan variabel yang berpengaruh paling rendah yaitu variabel LDR dengan nilai koefisien -0,001. Dari persamaan tersebut dapat terlihat bahwa variabel bebas (CAR dan NIM) berpengaruh positif terhadap ROA yang berarti meningkatnya Rasio CAR dan NIM perusahaan tersebut, sehingga ROA meningkat. Sedangkan variabel
BOPO, LDR, dan NPL memberikan pengaruh negatif terhadap ROA, yang berarti meningkatnya BOPO, LDR dan NPL mengakibatkan menurunnya ROA.

Pengujian koefisien regresi bertujuan untuk menguji signifikansi hubungan antara variabel independen (X) dan variabel dependen ( $\mathrm{Y}$ ) baik secara bersama-sama (dengan Uji F) maupun secara individual (dengan Uji t).

\section{Uji Determinasi}

Kekuatan pengaruh variabel bebas terhadap variasi variabel terikat dapat diketahui dari besarnya nilai koefisien determinan $\left(\mathrm{R}^{2}\right)$, yang berada antara nol dan satu. 
Model Summary ${ }^{\text {b }}$

\begin{tabular}{|c|c|c|c|c|c|}
\hline Model & $\mathrm{R}$ & R Square & Adjusted R Square & $\begin{array}{l}\text { Std. Error of } \\
\text { Estimate }\end{array}$ & Durbin-Watson \\
\hline 1 & $970^{\mathrm{a}}$ & ,941 & ,929 & ,21165 & 2,062 \\
\hline
\end{tabular}

a. Predictors: (Constant), NPL, BOPO, CAR, LDR, NIM

b. Dependent Variable: ROA

\section{Uji F (F-test)}

Uji F (F-test) dimaksudkan untuk mengetahui pengaruh variabel-variabel independen (CAR, BOPO, NIM,
LDR, NPL) secara simultan (bersama-sama) terhadap ROA perusahaan perbankan pada tahun 2014-2018.

Tabel 8 Hasil Regresi Uji F ANOVA $^{\mathrm{a}}$

\begin{tabular}{llrrrrr}
\hline Model & & Sum of Squares & df & Mean Square & F & Sig. \\
\hline \multirow{2}{*}{1} & Regression & 17,119 & 5 & 3,424 & 76,427 &, $000^{D}$ \\
\cline { 2 - 7 } & Residual & 1,075 & 24 &, 045 & & \\
\cline { 2 - 7 } & Total & 18,194 & 29 & & & \\
\hline
\end{tabular}

a. Dependent Variable: ROA

b. Predictors: (Constant), NPL, BOPO, CAR, LDR, NIM

Berdasarkan hasil pengujian diperoleh nilai $\mathrm{F}$ hitung sebesar 76,427 dengan signifikansi sebesar 0,000. Ternyata nilai signifikansi tersebut lebih kecil dari 0,05 $(0,000<0,05)$, hal ini berarti bahwa CAR, BOPO, NIM, LDR, dan NPL secara simultan berpengaruh terhadap ROA. Sehingga model dapat digunakan untuk memprediksi pengaruh capital adequacy ratio (CAR), biaya operasional pada pendapatan operasional (BOPO), net interest margin (NIM), loan to deposit ratio (LDR), dan non performing loan (NPL), terhadap profitabilitas bank umum konvensional periode 20142018. Hasil uji adjusted $\mathrm{R}^{2}$ pada penelitian ini diperoleh nilai sebesar 0,929. Hal ini menunjukkan bahwa profitabilitas dipengaruhi oleh capital adequacy ratio (CAR), biaya operasional pada pendapatan operasional (BOPO), net interest margin (NIM), loan to deposit ratio (LDR), dan non performing loan (NPL) sebesar $92,90 \%$, sedangkan sisanya sebesar 7,10\% dipengaruhi oleh faktor lain yang tidak diteliti dalam penelitian ini.

\section{Uji t (t-test)}

Uji t (t-test) ini dimaksudkan untuk mengetahui pengaruh secara parsial (individu) variabel- variabel independen (CAR, NPL, LDR, BOPO dan NIM) terhadap variabel dependen (ROA) atau menguji signifikansi konstanta dan variabel dependen.

\section{Tabel 8 Hasil Regresi Uji T}

\begin{tabular}{|c|c|c|c|c|c|c|c|c|}
\hline \multicolumn{9}{|c|}{ Coefficients $^{\mathrm{a}}$} \\
\hline & & \multicolumn{2}{|c|}{$\begin{array}{l}\text { Unstandardized } \\
\text { Coefficients }\end{array}$} & \multirow{2}{*}{$\begin{array}{c}\text { Standardized } \\
\text { Coefficients } \\
\text { Beta }\end{array}$} & \multirow[b]{2}{*}{$\mathrm{t}$} & \multirow[b]{2}{*}{ Sig. } & \multicolumn{2}{|c|}{ Collinearity Statistics } \\
\hline \multicolumn{2}{|c|}{ Model } & $\mathrm{B}$ & Std. Error & & & & Tolerance & VIF \\
\hline \multirow[t]{6}{*}{1} & (Constant) & 10,211 &, 721 & & 14,161 &, 000 & & \\
\hline & CAR &, 041 & ,005 &, 544 & 8,033 & ,000 &, 538 & 1,860 \\
\hline & BOPO &,- 110 & ,007 &,- 957 & $-15,546$ &, 000 & 650 & 1,539 \\
\hline & NIM &, 121 & ,049 &, 215 & 2,460 & ,021 & ,324 & 3,089 \\
\hline & LDR &,- 001 & ,003 &,- 025 &,- 290 & ,774 & ,330 & 3,034 \\
\hline & NPL &,- 214 & ,078 &,- 195 & $-2,733$ & 012 & ,484 & 2,067 \\
\hline
\end{tabular}

a. Dependent Variable: ROA

a. Capital Adequacy Ratio Berpengaruh terhadap Profitabilitas

Hasil statistik uji t untuk variabel Capital Adequacy Ratio (CAR) diperoleh nilai signifikansi sebesar 0,000 lebih kecil dari toleransi kesalahan $\alpha=0,05$. Oleh karena nilai signifikansi lebih kecil dari 0,05 berarti CAR berpengaruh terhadap ROA, dan koefisien regresi bernilai positif sebesar 0,041 ; berarti penelitian ini berhasil membuktikan hipotesis pertama yang menyatakan "Capital Adequacy Ratio berpengaruh positif terhadap ROA. CAR adalah rasio kinerja bank untuk mengukur kecukupan modal yang dimiliki bank untuk menunjang aktiva yang mengandung atau menghasilkan risiko, misalnya kredit yang diberikan. CAR merupakan indikator terhadap kemampuan bank untuk 
menutupi penurunan aktivanya sebagai akibat dari kerugian-kerugian bank yang disebabkan oleh aktiva yang berisiko dengan kecukupan modal yang dimilikinya (Dendawijaya, 2001).

b. Rasio Biaya Operasional terhadap Pendapatan Operasional Berpengaruh terhadap Profitabilitas

Hasil statistik uji t untuk variabel Biaya Operasional terhadap Pendapatan Operasional (BOPO) diperoleh nilai signifikansi sebesar 0,000 lebih kecil dari toleransi kesalahan $\alpha=0,05$. Oleh karena nilai signifikansi pada variabel BOPO lebih kecil dari 0,05, maka BOPO berpengaruh terhadap ROA, dan koefisien regresi bernilai negatif sebesar $-0,110$; berarti penelitian ini berhasil membuktikan hipotesis kedua yang menyatakan Rasio Biaya Operasional terhadap Pendapatan Operasional berpengaruh negatif terhadap ROA.

BOPO digunakan untuk mengukur tingkat efisiensi dan kemampuan bank dalam melakukan kegiatan operasinya. Mengingat kegiatan utama bank pada prinsipnya adalah bertindak sebagai perantara, yaitu menghimpun dan menyalurkan dana masyarakat, maka biaya dan pendapatan operasional bank didominasi oleh biaya bunga dan hasil bunga (Dendawijaya, 2003). Setiap peningkatan biaya operasional akan berakibat pada berkurangnya laba sebelum pajak yang pada akhirnya akan menurunkan ROA.

c. Net Interest Margin Berpengaruh terhadap Profitabilitas

Hasil statistik uji t untuk variabel Net Interest Margin (NIM) diperoleh nilai signifikansi sebesar 0,021 lebih kecil dari toleransi kesalahan $\alpha=0,05$. Oleh karena nilai signifikansi pada variabel Net Interest Margin (NIM) lebih kecil dari 0,05, maka NIM berpengaruh terhadap ROA dan koefisien regresi bernilai positif sebesar 0,121; berarti penelitian ini berhasil membuktikan hipotesis ketiga yang menyatakan "Net Interest Margin berpengaruh positif terhadap profitabilitas.

Net Interest Margin (NIM) mencerminkan risiko pasar yang timbul akibat berubahnya kondisi pasar, di mana hal tersebut dapat merugikan bank (Hasibuan, 2007). Net Interest Margin (NIM) digunakan untuk mengukur kemampuan manajemen bank dalam menghasilkan pendapatan dari bunga dengan melihat kinerja bank dalam menyalurkan kredit, mengingat pendapatan operasional bank sangat tergantung dari selisih bunga dari kredit yang disalurkan (Mahardian, 2008). Semakin besar Net Interest Margin (NIM) yang dicapai oleh suatu bank, maka akan meningkatkan pendapatan bunga atas aktiva produktif yang dikelola oleh bank yang bersangkutan, sehingga laba bank (ROA) akan meningkat.

d. Loan to Deposit Ratio Berpengaruh terhadap

\section{Profitabilitas}

Hasil statistik uji t untuk variabel Loan to Deposit Ratio (LDR) diperoleh nilai signifikansi sebesar 0,774 lebih besar dari toleransi kesalahan $\alpha=0,05$. Oleh karena nilai signifikansi pada variabel Loan to Deposit Ratio lebih besar dari 0,05, maka LDR secara parsial tidak berpengaruh terhadap ROA, dan koefisien regresi bernilai negatif sebesar $-0,001$; berarti penelitian ini berhasil membuktikan hipotesis keempat yang menyatakan LDR berpengaruh negatif positif terhadap ROA.

Loan to Deposit Ratio (LDR) merupakan ukuran likuiditas yang mengukur besarnya dana yang ditempatkan dalam bentuk kredit yang berasal dari dana yang dikumpulkan oleh bank. Loan to Deposit Ratio (LDR) mencerminkan kemampuan bank dalam membayar kembali penarikan dana yang dilakukan deposan dengan mengandalkan kredit yang diberikan sebagai sumber likuiditasnya, dengan kata lain seberapa jauh pemberian kredit kepada nasabah kredit dapat mengimbangi kewajiban bank untuk segera memenuhi permintaan deposan yang ingin menarik kembali uangnya yang telah digunakan oleh bank untuk memberikan kredit yang diberikan dengan total dana pihak ketiga. Semakin tinggi LDR, maka laba perusahaan semakin meningkat (dengan asumsi bank tersebut mampu menyalurkan kredit dengan efektif, sehingga jumlah kredit macetnya akan kecil).

Hasil penelitian menunjukkan bahwa LDR terbukti tidak berpengaruh terhadap profitabilitas, hal ini karena kredit yang disalurkan oleh bank tidak banyak memberikan kontribusi laba karena terdapat gap tinggi diantara bank-bank yang beroperasi dalam mengucurkan kredit. Jadi terdapat bank-bank yang kurang mengoptimalkan dana pihak ketiga, di sisi lain terdapat bank-bank yang berlebihan dalam memberikan kredit.

e. Non Performing Loan Berpengaruh terhadap Profitabilitas

Hasil statistik uji t untuk variabel Non Performing Loan (NPL) diperoleh nilai signifikansi sebesar 0,012 lebih kecil dari toleransi kesalahan $\alpha=0,05$. Oleh karena nilai signifikansi dari variabel NPL lebih kecil dari 0,05, maka NPL berpengaruh terhadap ROA, dan koefisien regresi bernilai negatif sebesar -0,214; berarti penelitian ini berhasil membuktikan hipotesis kedua yang menyatakan Non Performing Loan berpengaruh negatif terhadap profitabilitas. Credit risk adalah risiko yang dihadapi bank karena menyalurkan dananya dalam bentuk pinjaman kepada masyarakat (Susilo, 1999). Non Performing Loan (NPL) yang tinggi akan memperbesar biaya, sehingga berpotensi terhadap kerugian bank. Semakin tinggi rasio ini maka akan semakin buruk kualitas kredit bank yang menyebabkan jumlah kredit bermasalah semakin 
besar. Bank harus menanggung kerugian dalam kegiatan operasionalnya, sehingga berpengaruh terhadap penurunan laba (ROA) yang diperoleh bank (Kasmir, 2004).

Berdasarkan analisa data diketahui bahwa secara simultan CAR, BOPO, NIM, LDR, dan NPL berpengaruh signifikan terhadap ROA pada Bank Umum Kovensional periode 2012-2018. Secara parsial CAR, BOPO, NIM, dan NPL berpengaruh terhadap ROA. Sedangkan variabel LDR, secara parsial tidak berpengaruh terhadap ROA. Berpengaruhnya variabel CAR, BOPO, NIM, dan NPL terhadap ROA.

Variabel CAR pada bank berpengaruh terhadap ROA, karena CAR yang tinggi dapat melakukan ekspansi kredit sehingga akan meningkatkan pendapatan bunga yang berpengaruh terhadap peningkatan laba bank.

Variabel BOPO berpengaruh terhadap ROA, hal ini menandakan bahwa dengan meningkatnya BOPO pada perbankan menandakan perusahaan lebih banyak mengeluarkan biaya operasional dalam menghasilkan laba. Kondisi ini juga menandakan bahwa perusahaan yang menghasilkan laba besar tidak efisien dalam melakukan operasionalnya sehingga BOPO berpengaruh negatif terhadap ROA. Disamping itu BOPO juga merupakan variabel yang mampu membedakan bank yang mempunyai ROA diatas ratarata maupun bank yang mempunyai ROA dibawah ratarata. Dalam pengelolaan aktivitas operasional bank yang efisien dengan memperkecil biaya operasional bank akan sangat mempengaruhi besarnya tingkat keuntungan bank yang tercermin dalam ROA sebagai indikator yang mencerminkan efektivitas perusahaan dalam menghasilkan laba dengan memanfaatkan keseluruhan aktiva yang dimiliki.

Variabel NIM berpengaruh negatif terhadap ROA menandakan bahwa perubahan suku bunga serta kualitas aktiva produktif pada perusahaan perbankan dapat menambah laba bagi perusahaan. Bank telah melakukan tindakan yang berhati-hati dalam memberikan kredit sehingga kualitas aktiva produktifnya tetap terjaga. Dengan kualitas kredit yang bagus dapat meningkatkan pendapatan bunga bersih sehingga pada akhirnya berpengaruh terhadap laba bank. Pendapatan bunga bersih yang tinggi akan mengakibatkan meningkatnya laba sebelum pajak sehingga ROA pun bertambah. Setiap peningkatan NIM akan mengakibatkan peningkatan ROA. Hal ini terjadi karena setiap peningkatan pendapatan bunga bersih, yang merupakan selisih antara total biaya bunga dengan total pendapatan bunga mengakibatkan bertambahnya laba sebelum pajak, yang pada akhirnya mengakibatkan peningkatan ROA. Variabel NPL berpengaruh akibat semakin besar Bank Umum Konvensional melakukan operasionalnya terutama dalam ekspansi kredit berarti bertambahnya risiko yang muncul akibat semakin kompleksnya kegiatan perbankan adalah munculnya non performing loan (NPL) yang semakin besar. Selain itu juga kaitannya dengan ROA, dengan besarnya NPL dapat diartikan bahwa perusahaan memiliki risiko kredit macet yang besar dari pencairan kreditnya diharapkan dengan adanya pencairan kredit yang besar dapat menghasilkan laba yang besar pula bagi perusahaan sehingga dapat meningkatkan ROA perusahaan. Menurut catatan Bank Indonesia, kredit macet disebabkan antara lain penurunan kualitas kredit yang disebabkan oleh penurunan kondisi keuangan debitur, keterlambatan pembayaran, masalah pembayaran lain, buruknya prospek usaha debitur dan efek penerapan Peraturan Otoritas Jasa Keuangan tentang Penilaian Kualitas Bank Umum. Peningkatan NPL membutuhkan pencadangan yang lebih besar, sehingga mengurangi laba operasi.

Dari hasil persamaan regresi terlihat bahwa koefisien untuk variabel ini bernilai negatif, sehingga dapat diartikan bahwa pengaruh yang diberikan oleh variabel NPL terhadap ROA adalah negatif hal ini terjadi karena rata-rata nilai NPL bank-bank yang beroperasi pada periode tahun 2012-2018 sebesar 2,33\% masih dalam batas maksimum NPL yang disyaratkan oleh Otoritas Jasa Keuangan yaitu sebesar 5\%. Bank dapat menjalankan operasinya dengan baik jika mempunyai NPL dibawah $5 \%$.

LDR berpengaruh positif terhadap ROA, hal ini dikarenakan kredit yang disalurkan oleh bank banyak memberikan kontribusi laba karena pada tahun tersebut tidak terdapat gap antara bank-bank yang beroperasi pada saat itu dalam mengucurkan kredit. Hal ini ditunjukkan oleh nilai standar deviasi yaitu sebesar 20,17, dengan rata-rata LDR sebesar $100,76 \%$. Jadi bank-bank telah mengoptimalkan dana pihak ketiga. Namun kurang memperhatikan batas standar maksimal rasio LDR yang dikategorikan sehat yaitu $94 \%$.

\section{SIMPULAN DAN SARAN}

\section{Simpulan}

Berdasarkan hasil analisis dan pembahasan yang telah dijelaskan di bab sebelumnya, maka kesimpulan dari penelitian ini adalah:

1. Capital Adequacy Ratio berpengaruh positif dan signifikan terhadap ROA, hal ini dibuktikan dengan nilai koefisien regresi sebesar 8,033 dan nilai signifikansi sebesar 0,000 .

2. Rasio Biaya Operasional terhadap Pendapatan Operasional berpengaruh negatif terhadap ROA, hal ini dibuktikan dengan nilai koefisien regresi sebesar -15.546 dan nilai signifikansi sebesar 0,000 . 
3. Net Interest Margin berpengaruh positif terhadap ROA, hal ini dibuktikan dengan nilai koefisien regresi sebesar 2,460 dan nilai signifikansi sebesar 0,021 .

4. Loan to Deposit Ratio tidak berpengaruh terhadap profitabilitas, hal ini dibuktikan dengan nilai koefisien regresi sebesar 0,290 dan nilai signifikansi sebesar 0,774 .

5. Non Performing Loan berpengaruh negatif terhadap profitabilitas, hal ini dibuktikan dengan nilai koefisien regresi sebesar $-2,733$ dan nilai signifikansi sebesar 0,012 .

6. Capital Adequacy Ratio (CAR), Biaya Operasional pada Pendapatan Operasional (BOPO), Net Interest Margin (NIM), Loan to Deposit Ratio (LDR), dan Non Performing Loan (NPL) berpengaruh terhadap ROA bank umum konvensional pada periode 2012-2018, hal ini dibuktikan dengan nilai $F$ hitung sebesar 76,427 dengan signifikansi sebesar 0,000. Hasil uji adjusted R2 pada penelitian ini diperoleh nilai sebesar 0,929. Hal ini menunjukkan bahwa profitabilitas dipengaruhi oleh capital adequacy ratio (CAR), biaya operasional pada pendapatan operasional (BOPO), net interest margin (NIM), loan to deposit ratio (LDR), dan non performing loan (NPL)sebesar 92,90\%, sedangkan sisanya sebesar $7,10 \%$ dipengaruhi oleh faktor lain yang tidak diteliti dalam penelitian ini.

\section{Saran}

Penelitian selanjutnya juga disarankan untuk meneliti faktor-faktor lain yang berpengaruh terhadap profitabilitas diantaranya Intellectual Capital, dan Investasi Teknologi Informasi.

\section{DAFTAR PUSTAKA}

Adhista Setyarini(2019), ANALISIS PENGARUH CAR, NPL, NIM, BOPO, LDR TERHADAP ROA (Studi Pada Bank Pembangunan Daerah Di Indonesia Periode 2015-2018) Research Fair Unisri 2019 P- ISSN: 2550-0171 Vol 4, Number 1, Januari 2020 E-ISSN: 2580-5819.

Agus Sartono, 2001. Manajemen Keuangan Teori dan Aplikasi. Yogyakarta: BPEF-YOGYAKARTA.

Andy Setiawan, Bambang Hermanto (2017) Jurnal Comparative study : determinant on banking profitability between buku 4 and buku 3 bank in Indonesia BENEFIT Jurnal Manajemen dan Bisnis Volume 2, Nomor 1, Juni 2017ISSN: 1410-4571 E-ISSN: 2541-2604

Anne Maria (2015) pengaruh Capital Adequacy Ratio, Biaya Operasional terhadap Pendapatan Operasional, Margin Bunga Bersih, Rasio Setoran Pinjaman terhadap Return On Asset pada 10 bank teratas 2013 di Indonesia.

Bambang Riyanto, 2001. Dasar-dasar Pembelanjaan Perusahaan. BPFE, Yogyakarta.

Bank Indonesia. 2004. Surat Edaran Bank Indonesia Nomor 6/23/DPNP Perihal Sistem Penilaian Tingkat Kesehatan Bank. www.bi.go.id.

Bank Indonesia. 2007. Peraturan Bank Indonesia No. 9/13/PBI/2007 tanggal 01 November 2007. Jakarta

Catur Wahyu Endra Yogianta (2013), Analisis pengaruh CAR, NIM, LDR, NPL DAN BOPO terhadap profitabilitas studi pada bank umum yang go publik di bursa efek indonesia periode tahun 2002-2010. Jurnal Bisnis STRATEGI Vol. 22 No. 2 Des. 2013

Darmawi, Herman, 2011. Manajemen Perbankan, Penerbit PT Bumi Aksara, Jakarta.

Debby Andesfa, Erni Masdupi (2018) Effect of Financial Ratio on Profitability of Commercial Banks; a Systematic Literature Review. DOI: 10.2991 / piceeba2-18.2019.55ID Corpus: 182506187 Prosiding Konferensi Internasional Padang ke-2 tentang Pendidikan, Ekonomi, Bisnis dan Akuntansi (PICEEBA-2 2018) Atlantis Press

Dendawijaya, Lukman, 2009, Manajemen Perbankan, Ghalia Indonesia, Jakarta.

Fahmi, Irham. 2011. Analisis Laporan Akuntansi. Bandung: ALFABETA.

Fahmi, Irham. 2012. “Analisis Kinerja Keuangan”, Bandung: Alfabeta

Farah Margaretha, Adisty Adisty.(2017) Factors That Affect Profitability of Banks Comparative Study Between Indonesian And Hong Kong, KINERJA Volume 21, No. 1, 2017 Page.88-10 DOI: https://doi.org/10.24002/kinerja.v21i1.1036.

Ghozali, Imam. 2005. Aplikasi Analisis Multivariate dengan SPSS. Semarang: Badan Penerbit UNDIP.

Halim, Abdul dan Mamduh M. Hanafi. 2009. Analisis Laporan Keuangan. Edisi 4. UPP STIM YKPN. Yogyakarta.

Handono Mardiyanto. (2009). Intisari Manajemen Keuangan: Teori, Soal dan Jawaban. Jakarta: Grasindo

Hantono (2017) Effect of CAPITAL ADEQUACY RATIO (CAR), LOAN TO DEPOSIT RATIO (LDR) and NON PERFORMING LOAN (NPL) to RETURN ON ASSETS (ROA) listed in banking in indonesia stock exchange. International Journal of Education and Research Vol. 5 No. 1 January 2017 ISSN: 2411-5681 www.ijern.com.

Ismail. 2009. Manajemen Perbankan: Dari Teori Menuju Aplikasi. Jakarta: Kencana. 
Kasmir, 2014. Analisis Laporan Keuangan, Edisi Pertama, Cetakan Ketujuh. Jakarta: PT. Rajagrafindo Persada.

Kuncoro, Mudrajat, Suhardjono. 2011. Manajemen Perbankan Teori dan Aplikasi. Edisi ke 2. Yogyakarta: BPFE Yogyakarta

Monica (2019) Analisis pengaruh CAR, NPL, NIM, BOPO dan LDR Terhadap ROE pada Bank Umum Swasta Nasional Devisa di Indonesia jurnal manajemen bisnis dan kewirausahaan/volume 3/no.3/mei - 2019: 08-17.

Pedro Soares dam Muhammad Yunanto (2018). THE EFFECT OF NPL, CAR, LDR, OER AND NIM TO BANKING RETURN ON ASSET. International Journal of Economics, Commerce and Management United Kingdom Vol. VI, Issue 3, March 2018. Licensed under Creative Common Page 40 http://ijecm.co.uk/ ISSN 23480386

Ririn Poerwanti dan Titis Puspitaningrum Dewi Kartika (2018) The Effect Of CAR, NPL \& LDR On The Profit Improvement Of Regional Development Bank In Indonesia By Using Credit Growth As Intervening Variable (Research on Regional Development Banks in Java, Bali \& NTT) Period 2011 - 2015, International Journal Of Entrepreneurship And Business Development Vol 1 No 2 (2018): March 2018

Riyadi Slamet. 2009. Banking Asset \& Liability Management. Jakarta: Lembaga Penerbit Fakultas Ekonomi, Universitas Indonesia.

S. Munawir, 2007, Analisa Laporan Keuangan. Liberty, Yogyakarta.

Samryn. 2011. Pengantar Akuntansi Mudah Membuat Jurnal Dengan Pendekatan Siklus Transaksi. Jakarta: PT. Raja Grafindo Persada

Surat Edaran Bank Indonesia No.6/ 23/DPNP tanggal 31 Mei 2004

Surat Edaran Otoritas Jasa Keuangan Nomor 14 /SEOJK.03/2017 tentang penilaian tingkat kesehatan bank umum

Surat Edaran Otoritas Jasa Keuangan Nomor 14/SEOJK.03/2017 tentang Penilaian Tingkat Kesehatan Bank Umum.

Sutrisno. (2009), Manajemen Keuangan Teori, Konsep dan Aplikasi, Edisi Pertama, Cetakan Ketujuh, Penerbit Ekonisia, Yogyakarta.

Taswan. 2006. Manajemen Perbankan. Yogyakarta: UPP STIM YPKP

Taswan. 2010. Manajemen Perbankan, Konsep, Teknik, dan Aplikasi. Edisi Kedua. Yogyakarta: UPP STIM YKPN.
Veithzal Rivai. (2007). Bank and Financial Institute Management. Jakarta: PT. Raja Grafindo Persada.

vol 4 no 1 (2015): calyptra: jurnal ilmiah mahasiswa universitas surabaya. vol 4 no 1.

Weston J. Fred dan Thomas E. Copeland. 1995. Manajemen Keuangan Jilid I. Terjemahan Jaka Wasana dan Kibrandoko. Binarupa Aksara. Jakarta.

Zulkifli Z dan Rispa Eliza (2018) MIX. Determinan Net Interest Margin Perbankan Nasional: Jurnal Ilmiah Manajemen, Volume 8, No. 3, Oktober 2018. ISSN: 2088-1231 E-ISSN: 2460-5328 DOI dx.doi.org/10.22441/mix. 2018.v8i3.012.

Usman, Husaini. 2003. Metodologi Penelitian Sosial. Jakarta: Bumi Aksara

Ghozali, Imam. 2011. “Aplikasi Analisis Multivariate Dengan Program SPSS". Semarang: Badan Penerbit Universitas Diponegoro.

Dendawijaya, Lukman. 2001. Manajemen Perbankan. Jakarta: Penerbit Ghalia Indonesia.

Hasibuan, M.S.P. 2007. Dasar-Dasar Perbankan. Jakarta: PT. Bumi Aksara.

Susilo, Sri, Sigit Triandaru, A. Totok Budi Santoso. 1999. Bank dan Lembaga Keuangan Lain. Cetakan Pertama. Jakarta: Salemba Empat.

Mahardian, Pandu 2008. "Analisis Pengaruh Rasio CAR, BOPO, NPL, NIM dan LDR terhadap kinerja keuangan perbankan". Program magister manajemen. Universitas Diponegoro Semarang. 